ISBN 978-93-84468-86-6

2016 International Research Conference on Practices in Law Business and Education

(PLBE-16)

Pattaya (Thailand) Dec. 16-17, 2016

\title{
Land Use Pattern and Climate Related Risks Assessment in Angat River Basin: The Case of Riverfront Barangays in Baliwag and Bustos, Bulacan, Philippines
}

\author{
Randy H. Po, Reynaldo C. Cruz, *Alberto J. Valenzuela, and Alvin V. Nuqui \\ *Bulacan State University, City of Malolos, Bulacan, Philippines
}

\begin{abstract}
Almost half of the municipalities traversed by the Angat River have population density levels substantially higher than the provincial average of 1,525 persons per square kilometer while experiencing slowgrowing settlement trend. Information generated using Geographic Information System (GIS) reveals that the builtup residential and industrial uses patterns in these towns are concentrating around the Angat River where natural hazards are common. Focusing on the towns of Baliwag and Bustos particularly on large communities living near or within the banks of Angat River as case study areas, GIS data confirms increased pattern of settlement expansion around the river. This resulted in very high exposure of these populations and its built environment to climaterelated risks.

Using qualitative and quantitative research methods including GIS tools, the study examined how land use patterns affect climate-related risks particularly by flooding hazard. This research also investigated the current institutional policies and performance of the local governments relative to managing risks at the Angat River basin including adaptation measures, resource mobilization, response and strategies related to land use considering that these areas are highly exposed to climate risks and that loss of lives and properties in these areas are recorded annually. This study demonstrated disasters, hazard and climate risk in the Angat River basin mitigated with improved land use planning and management as the long-term solution in reducing expenditures in disaster response and rehabilitation in areas defined as danger zones.
\end{abstract}

Keywords: Land use patterns, climate related risks, dominant land use and river basin

\section{Introduction}

Climate change is here, and in effect, extreme weather condition is happening such as increased rainfall intensity and duration that resulted in high and frequent flooding. This new paradigm has made almost all nations around the world exert efforts to respond to the challenges of mitigating the impacts of global warming. Philippines is among the nations who are not spared by the impacts brought by climate-related risks or hazards. In fact, our country is considered as one of the disaster-prone nations because of our geographic location and topography.

As an archipelago, we are highly exposed to hydro-meteorological hazards such as flooding, storm surges and rising of tides. When it comes to hydro-meteorological hazards, the Province of Bulacan is among the places in this country where water-based related hazards are prevalent. The Angat River Basin in particular, is a host to the longest river system in Bulacan, the Angat River, where massive volume of water continuously flow that could potentially cause large flooding in the towns that it traverses. The municipalities crossed by the Angat River are the most susceptible to climate-related risks or hazards more particularly by flooding. Moreover, the 
risks in the communities living along the river channels are increasing overtime due to the arrival of extreme weather events such as typhoon Ondoy and several habagat-enhanced typhoons. Based on the accounts of the Provincial Disaster and Risks Reduction Management Office (PDRRMO), it is the community near the river channels where number of death is recorded; properties destroyed and damage to infrastructure and agriculture are greatest. In spite of this condition, built-up areas are still observed to thrive along the river channels, which are evidenced by the decreasing open spaces in the river banks due to the presence of settlements and other similar built-environment. Focusing on the towns of Baliwag and Bustos, particularly on the riverfront Barangays of Angat River as the case study, risks exposure and vulnerability assessment were investigated using scientific approach.

\section{Objectives of the Study}

The main focus of this study was to assess the dominant land use patterns in the barangays fronting the Angat River in the Municipalities of Baliwag and Bustos in aid of developing knowledge capabilities in risk management and planning.

Four specific issues were dealt with in the study:

- Assess the dominant land use patterns in the Angat River Basin using the case of Baliwag and Bustos municipalities.

- Determine the extent of effects the known climate-change related risks or hazards in the land use patterns in Angat River Basin in particular and the Bulacan Province in general.

- Identify the climate risks adaptation measures and strategies particularly alternative land uses and policies that may be developed in these municipalities.

- Identify the knowledge capabilities in risk management and planning that needs to be developed at the municipal and barangay level.

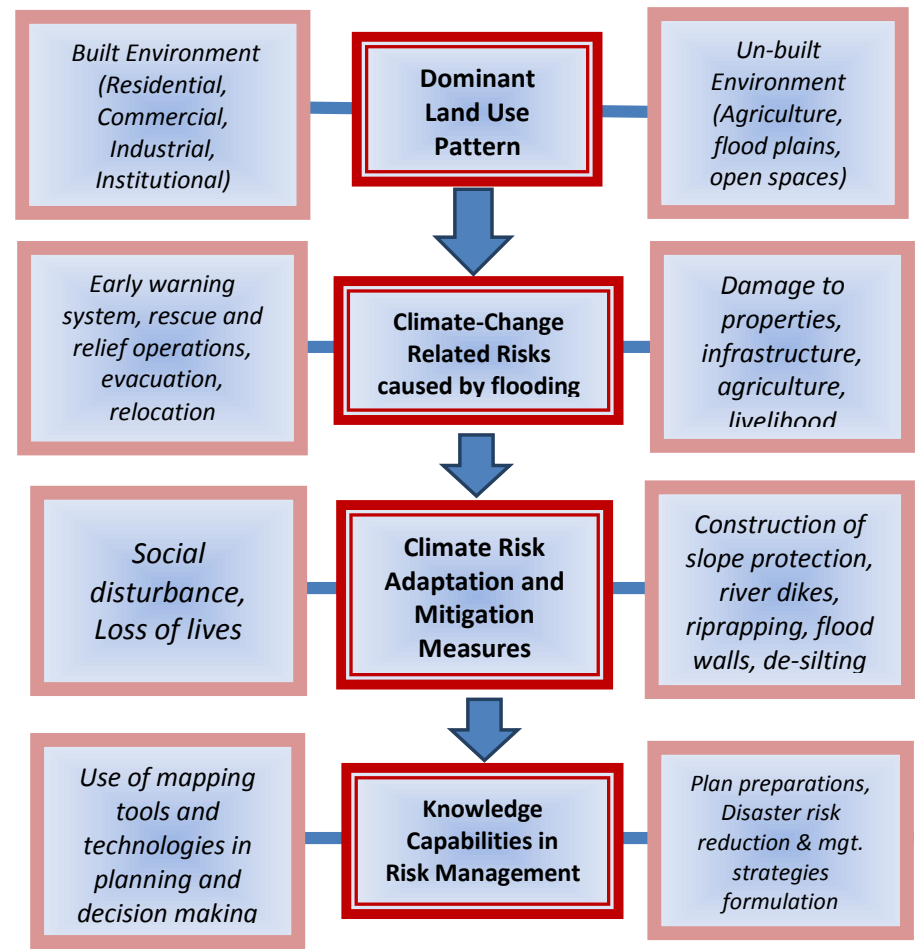

Fig. 1 Conceptual Framework

First is the study of the dominant land use pattern in the research area. This describes how the river front barangays in the Municipalities of Baliwag and Bustos utilize their lands over time. It can be classified as Built and Un-Built Environment. 
Second, these riverfront barangays are constantly subjected to forces of nature, flooding hazard in particular. This is the pronounced hazard in the subject area and continuously being enhanced by the climate change. At any rate, these climate-related risks may result into possible disasters in the river front communities that could lead to damage to properties, infrastructure, agriculture, livelihood or economic disruption or social disturbance and at worse loss of lives.

Third, to ensure the safety and general welfare of the riverfront communities, the government continues to carry out climate risk adaptation and mitigation measures. Interventions include implementation of soft and hard projects. Soft projects refer to non-infrastructure interventions including early warning systems, rescue, and relief, evacuation and relocation. While hard or infrastructure interventions include construction of slope protection, river dikes, riprapping, flood walls and de-silting of waterways.

Finally, looking at these variables, the study would like to contribute to the knowledge capabilities in risk management in the research area. These could be on the aspect of plan preparations, disaster risk reduction and management, and use of mapping tools in enhancing planning and decision-making skills of the stakeholders.

\section{Materials and Methods}

This study used mixed methods of research in order to answer the focus questions described above. Quantitative and qualitative research approaches were carried out concurrently in the gathering and analyses of data within the project area.

Quantitative research specifically focused on gathering and analyzing statistical data and spatially-referenced maps. Since establishing land use patterns is one of the major target outputs, maps were the primary data needs in this study. In particular, geo-hazard maps or flood maps that have Geographic Information System (GIS) properties were sourced from national and provincial governments. Statistical information including population count and land area were part of the primary data utilized in this research. Qualitative research, on the other handused interviews to obtain data and information from focal persons on the land use and vulnerability condition of riverfront communities in the study area. Purposive sampling method for the interview was employed particularly to the members of the Barangay Government of the affected riverfront communities. The basis in selecting the target sample is the GIS-generated 100-meter and 200-meter buffer zone from the Angat

River. Those Barangays with built-up areas embraced by the buffer zone was selected to represent the respondents.

Geographic Information System (GIS) software, particularly Geomatica version 13.0, was used to make overlay of two or more maps possible. The spatial analysis used (overlay analysis) determines the exposed population and properties to flooding hazards. These exposed elements were multiplied to the calculated built-up densityto determine the number of population at risks, while land use exposure cost employed the use of unit cost per hectareof land use suggested in the mainstreaming guidelines of the Disaster Risk Assessment-Climate Vulnerability Assessment (DRA-CVA) report.

\section{Research Instruments}

In the data gathering, one significant method that was employed was through the request of Comprehensive Land Use Plans and various thematic and analytical maps from the Provincial Government of Bulacan and Municipalities of Baliwag and Bustos. As part of the research, the Barangay Officials or equally competent representatives of the Barangay government were selected as respondent of the guided questionnaire. The guide questions were designed to easily gather the required information from the respondents of this study.

\section{Data Gathering Procedure}

Since the researcher dealt with local government units in acquiring primary data, a personal visit or formal letter request was prepared to obtain a copy or access the needed documents at the Municipalities of Baliwag and 
Bustos particularly the Comprehensive Land Use Plans. Historical maps depicting previous land use condition were included in the request to determine changes in land use overtime.

The researcher personally coordinated with the national and provincial government to request for copies of maps and ask them permission to use the information in this study. The researcher coordinated down to the level of barangays which could possibly hold maps or records significant to this study.

Satellite imageries and/or topographic maps were used as basic material in establishing land use changes. These were sourced from the internet, Google Earth in particular, and from PPDO data bank.

\section{Data Processing and Statistical Treatment}

Statistical information were arranged in table format to easily establish historical and individual relationship. These are arranged by Municipality and per Barangay. First, the data was presented covering the whole municipal territory and then focus is given in the riverfront barangays. The statistical information were integrated with the spatially referenced map or flood maps to produce the required outputs. Population in particular were integrated to the maps by means of overlay analysis to establish its geographical character. The Geographic Information System (GIS) was the primary tool in making the overlay analysis particularly Geomantic Software. GIS as a modern planning tool, organized the necessary geographic data (population and flood levels) to map the required information for the barangays in the Municipalities of Baliwag and Bustos fronting the Angat River. Primarily, the overlay analysis capability of the GIS can process two or more maps in order to establish historical land use pattern.

\section{Results and Discussion}

This study focused its analysis on land use patterns and the presence of climate-related risks in the communities fronting the Angat River within the territorial jurisdiction of the Municipalities of Baliwag and Bustos. In particular, the communities covered by this research include barangays Tibag, Poblacion, San Jose and Tiaong in the Municipality of Baliwag and barangays Poblacion, San Pedro and Sta. Barbara in the Municipality of Bustos.

The use of purposive sampling method was employed particularly to the Barangay Officials or other key informants in the Barangay Government. The qualitative data described previously were acquired using interviews particularly on key informants that have deep understanding of the land use and disaster related risks in the area. Since the population of the study area was too large, primary data using maps from authorized agencies were the primary bases in drawing historical and actual land uses of the area.

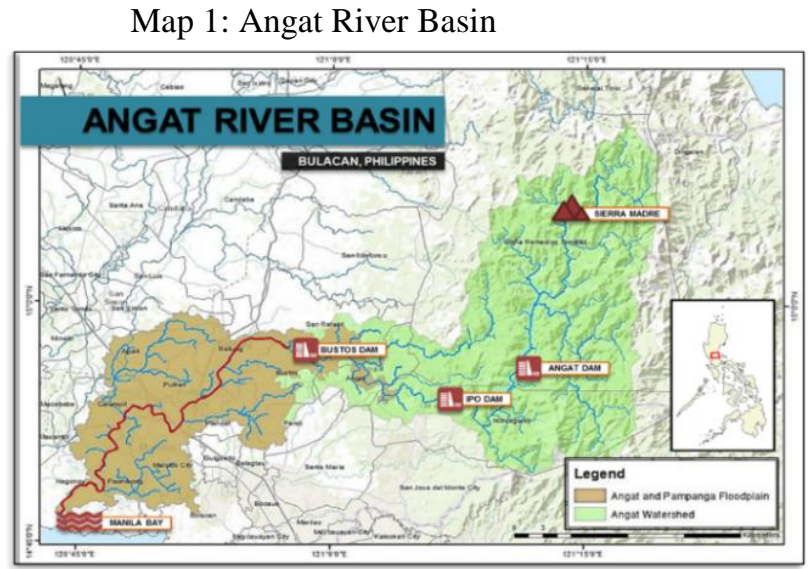

Source: UP-DREAM Program-Flood Forecast for Angat River Basin
Map 3: 1997 Built-up Area, Municipality of

Baliwag and Bustos

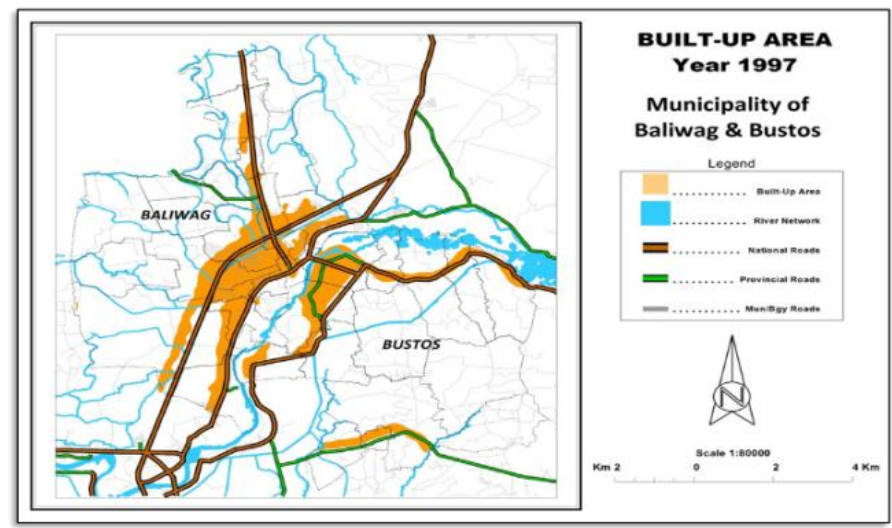

Source of base map: Provincial

Physical Framework Plan, 1997-2007 
Using the procedures mentioned, the findings of the study may be summarized as follows:

The dominant land use of the riverfront Barangays in the Angat River Basin using the case of Baliwag and Bustos is still open space or un-built environment. Only Barangays Poblacion and Sabang in the Municipality of Baliwag and Barangay Poblacion in the Municipality of Bustos have space allocation for built-up area higher than its open space. However, the dominant land use in the research area revealed a decreasing pattern from the year 1997 to 2007. The pattern also showed that the built-environment was slowly dominating the land use in these riverfront barangays particularly towards the direction of the river.

Climate-change related risk investigated in the research study focuses on flooding as the leading known hazard in the riverfront barangays. Based on the hazard map prepared by the Mines and Geosciences Bureau, areas fronting the Angat River belong to high flooding susceptibility level and low to medium flooding susceptibility in the immediate surroundings. Applying a buffer of 100-meter and 200-meter from the river banks, the analysis revealed that there are built-up areas seated on high flooding susceptibility level. The study also showed that the said built-up within the high flood susceptible areas are growing over time during the observed time line (year 2000 and 2010). The exposed built-up area to varying level of flood susceptibility in year 2010 is estimated to have a combined population of more than 27,000 and land use exposure cost of more than $\mathrm{PhP} 15$ Billion for both riverfront barangays in the Municipality of Baliwag and Bustos. Considering the vulnerability of these exposed population, the qualitative research revealed that the communities in the riverfront barangays were at a very high risk when flooding hazard occurred.

TABLE I Built and Un-Built Environment Area Tabulation

\begin{tabular}{|c|c|c|c|c|c|c|c|c|c|c|c|}
\hline \multirow[t]{2}{*}{$\begin{array}{c}\text { Municipality / } \\
\text { Barangays }\end{array}$} & \multicolumn{2}{|c|}{$\begin{array}{c}\text { Built } \\
\text { Environment } \\
\text { (Hectares) }\end{array}$} & \multicolumn{2}{|c|}{$\begin{array}{c}\text { Un-Built } \\
\text { Environment } \\
\text { (Hectares) }\end{array}$} & \multirow{2}{*}{$\begin{array}{c}\% \\
\text { Increase } \\
\text { in the } \\
\text { Built- } \\
\text { Environ } \\
\text { ment }\end{array}$} & \multirow[b]{2}{*}{$\begin{array}{c}\text { Municipality / } \\
\text { Barangays }\end{array}$} & \multicolumn{2}{|c|}{$\begin{array}{c}\text { Built } \\
\text { Environment } \\
\text { (Hectares) }\end{array}$} & \multicolumn{2}{|c|}{$\begin{array}{c}\text { Un-Built } \\
\text { Environment } \\
\text { (Hectares) }\end{array}$} & \multirow{2}{*}{$\begin{array}{c}\% \\
\text { Increase in } \\
\text { the Built- } \\
\text { Environme } \\
\text { nt }\end{array}$} \\
\hline & 1997 & 2007 & 1997 & 2007 & & & 1997 & 2007 & 1997 & 2007 & \\
\hline \multicolumn{6}{|c|}{ Municipality of Baliwag } & \multicolumn{6}{|c|}{ Municipality of Bustos } \\
\hline 1. Makinabang & 44.14 & 107.98 & 216.36 & 152.52 & 144.63 & 1.Bonga Mayor & 25.44 & 27.67 & $\begin{array}{c}177.3 \\
3 \\
\end{array}$ & 175.1 & 8.77 \\
\hline 2. Poblacion & 28.17 & 29.97 & 19.12 & 17.31 & 6.39 & 2.Bonga Menor & 25.08 & 34.7 & $\begin{array}{c}367.2 \\
9\end{array}$ & $\begin{array}{c}357.6 \\
7\end{array}$ & 38.36 \\
\hline 3. Sabang & 71.12 & 84.17 & 146.19 & 133.14 & 18.35 & 3. Cambaog & 32.31 & 43.35 & $\begin{array}{c}136.8 \\
6 \\
\end{array}$ & $\begin{array}{c}125.8 \\
3 \\
\end{array}$ & 34.17 \\
\hline 4. San Jose & 19.57 & 33.14 & 35.11 & 21.54 & 69.34 & 4. Poblacion & $\begin{array}{c}123.7 \\
9\end{array}$ & 128.16 & $\begin{array}{c}118.1 \\
1\end{array}$ & $\begin{array}{c}113.7 \\
4\end{array}$ & 3.53 \\
\hline 5. Sta. Barbara & 54.14 & 58.63 & 88.69 & 84.2 & 8.29 & 5. San Pedro & 97.45 & 103.16 & $\begin{array}{c}160.1 \\
5 \\
\end{array}$ & $\begin{array}{c}154.4 \\
4 \\
\end{array}$ & 5.86 \\
\hline 6. Tarcan & 124.18 & 136.91 & 759.59 & 746.86 & 10.25 & 6. Tanawan & 28.45 & 31.87 & 95.38 & 91.96 & 12.02 \\
\hline 7. Tiaong & 2.54 & 10.02 & 54.37 & 46.89 & 294.49 & 7. Tibagan & 37.12 & 47.29 & $\begin{array}{c}249.4 \\
3 \\
\end{array}$ & $\begin{array}{c}239.2 \\
6 \\
\end{array}$ & 27.4 \\
\hline 8. Tibag & 3.18 & 6.6 & 22.94 & 19.52 & 107.55 & & & & & & \\
\hline
\end{tabular}

Adaptation measures are essentially employed by the riverfront communities including the close monitoring of the water level in the Angat River during typhoons, early warning systems, and evacuation to higher grounds or designated evacuation centers when flood waters from the river get very high. Mitigation and preparedness strategies are mainly employed by the Municipal Governments of Baliwag and Bustos, together with the national and provincial governments. Such measures include implementing of infrastructure projects including construction of river dikes and other slope stabilization measures to mitigate the impact of flooding in the riverfront communities. Relocation of informal settler families is also an effective mitigation measure being employed in the research area led by the Provincial Government of Bulacan and National Housing Authority. 
Map 5: 2007 Built-Up Area Overlaid with

Flooding Map \& Buffer Zone, Riverfront Barangays of

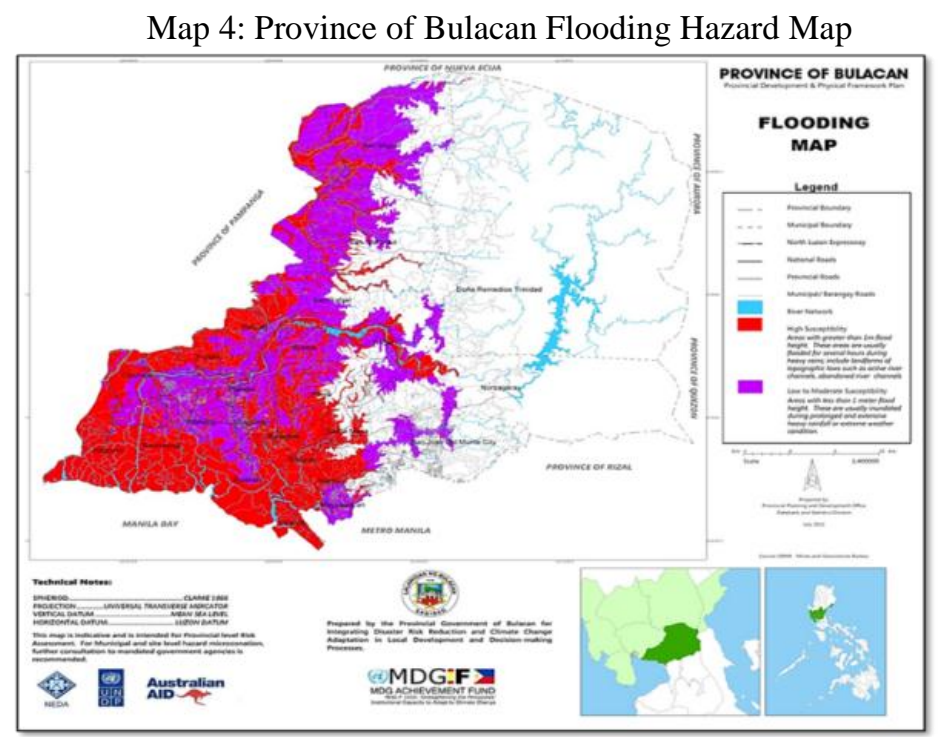

Source: Bulacan DRA-CCVA Report,

December 2013, DENR-MGB Regional Office III
Baliwag \& Bustos

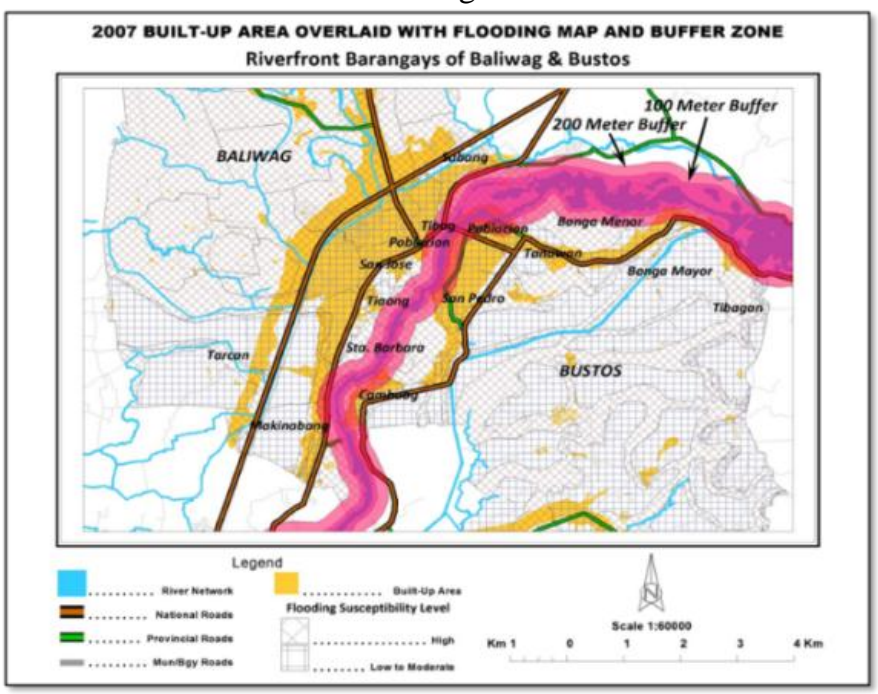

Source of base map: Prov'l.Dev’t. \& Physical Framework Plan, 2010-2030, DENR-MGB Regional Office III

The Municipalities of Baliwag and Bustos have no updated Comprehensive Land Use Plans (CLUPs) and Zoning Ordinances (ZOs) to guide the overall physical development of their respective town. Aside from having an outdated CLUPs and ZOs, the prevailing documents are not responsive to the new regulations and policies of disaster risk reduction and climate change adaptation. The research also revealed the absence of locally generated hazard maps that would show the Barangays the danger zones along the Angat River. The only available hazard maps that can be used are the small-scale maps generated by the provincial and national governments. These hazard maps are not adequate as planning reference to help the riverfront barangays in managing flood risks in their area. However, the local Disaster Risks Reduction and Management Offices of Baliwag and Bustos as well as the Barangays are said to be equipped with capabilities relative to disaster preparedness and rescue operations.

\section{Conclusions}

Based on the findings of the study, the following conclusions were drawn:

The un-built environment showed a decreasing trend from 1997 to 2007 because these open spaces are being converted for other purposes mainly as settlements area. The trend is brought by the pressure from the growing need for housing facilities as a consequence of increasing population.

The pattern of growth of the built environment in the research area has resulted in the increase in the number of population and properties exposed to the leading climate-change-related risk or flooding hazard in the Angat River. It is also concluded that the larger the population exposed, the higher the risks and the larger the built-up area, the higher the land use exposure cost. Further, this would mean that the government may have to allocate more funding for mitigation, rescue, and post-disaster operations whenever flood disaster happens.

Adaptation and mitigation measures are both employed in the riverfront barangays in dealing with the known climate-change related risks in the research area and has been attested to be effective. The adaptation measures can only lower the disaster risks but cannot eliminate the potential threat to the lives and properties of the riverfront communities. In this premise, the research concluded that relocating the population exposed to hazard 
and maintaining the high flood-susceptible area as open space are the best means to eliminate exposure to flooding hazards of the built environment, hence, removing disaster risks in the research area.

Knowledge in land use and planning capabilities are assessed to be insufficient in both Municipal Government of Baliwag and Bustos. However, in terms of disaster preparedness and adaptation skills, the Municipal Government and the riverfront Barangays may have the capabilities to deal with the impact of the occurrence of flooding hazard in the Angat River.

\section{Recommendations}

- Concerned officials of government, national and local, exert all efforts to keep Angat River Basinfree from settlements particularly to those areas classified as high susceptible to flooding. Barangay officials likewise, should be vigilant and responsible for ensuring that no illegal structures are being constructed within the banks of Angat River. The communities must also take part in this responsibility by involving themselves in the monitoring of activities along the Angat River. To raise their awareness, the riverfront communities should understand the climate-related risks or hazards present in their area. Information drive needs to be conducted to disseminate the flood hazard maps to every Barangays especially to those fronting the Angat River. An education campaign for the riverfront communities on the danger of living along or near the Angat River must also be done.

- The growth of built-up area should be prevented from going towards the river where climate-change related risks are very high. Areas within high flood susceptibility level should be classified as no build zone. This can be done by incorporating this policy in the updating of the comprehensive land use plan and zoning ordinance of the Municipality of Baliwag and Bustos. Employing both adaptation and disaster mitigation strategies in the Barangays fronting the Angat River is strongly recommended. The level of susceptibility and vulnerability of an area should be first established to determine the best intervention to employ. For the communities exposed to high level of flood susceptibility, relocation as a form of mitigation measure is regarded to be the best approach. This will permanently avert the families under constant threat or living in high risks areas due to their exposure to high flooding hazard. For the adaptation measures, particularly to the communities living within the low to medium level of flood susceptibility, the local government should work together with the Barangay in increasing their resiliency. This would mean improving the communities' socio-economic condition such as increasing access to utilities, support facilities, and employment.

- The municipalities need to enhance collaboration efforts with national and provincial officials for training assistance on enhanced Disaster Risk Reduction Management (DRRM) strategies. Another essential skill and technology that need to be acquired is the use of Geographic Information System (GIS) as a modern tool to improve their data management and spatial analysis for making better and effective decisions in development planning and DRRM. In the updating or re-formulation of their CLUPs and ZOs, it is recommended that the Municipalities of Baliwag and Bustos, through their Municipal Planning and Development Office, seek the technical assistance of the Housing and Land Use Regulatory Board Regional Office 3 or the PPDO to guide them in preparing the said planning documents. It is also recommended to conduct a community-based flood mapping using GIS in order to produce a more accurate and updated hazard map in each river.

\section{References}

[1] Briones \&Castro.Effective Management of a Tropical Watershed: The Case of the Angat River Watershed in the Philippines. Water International, 11: 4. 1986. pp. 157-161 https://doi.org/10.1080/02508068608686432

[2] FAO.Climate Related Risks and Extreme Events. FAO Contribution to "The Nairobi Work Programme (NWP) on Impacts, Vulnerability and Adaptation to Climate Change. 23 February 2007 
[3] Jieh-JiuhWang.Integrated Model Combined Land-Use Planning and Disaster Management: The Structure, Context and Contents. Emerald.National Science Council. Taiwan. Vol. 21 Iss: 1. 2012. pp. 110-123

[4] Kalnay, E. \& Cal, M. Impact of Urbanization and Land-Use Change on Climate.Nature Publishing Group/Vol 423. 29 May 2003. pp. 528-531, https://doi.org/10.1038/nature01675

[5] Mercer, J., et.al.Disaster Risk Reduction or Climate Change Adaptation: Are We Reinventing the Wheel?.Journal of International Development J. Int. Dev. 22.John Wiley \& Sons, Ltd. 2010. pp. 247-264

[6] Nowlan, L \& Bakker, K. Delegating Water Governance: Issues and Challenges in the BC Context. Report for BC Water Governance Project. UBC Program on Water Governance. November 2007

[7] Provincial Government of Bulacan-PPDO.DRR/CCA-EnhancedProvincial Development and Physical Framework Plan 2010-2030

[8] Provincial Government of Bulacan-PPDO.Provincial Physical Framework Plan 1997-2007

[9] Trenberth, K. Rural Land-Use Change and Climate. Nature Publishing Group. Vol. 427. 15 January 2004. pp. 213

[10] Wilby and Keenan.Adapting to Flood Risk Under Climate Change. Progress in Physical Geography.Sage. 29 March 2012

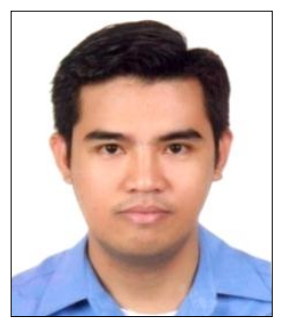

\section{Engr. Randy H. Po}

$\mathrm{He}$ is currently the Information Technology Officer II of the Provincial Planning and Development Office of the Provincial Government of Bulacan. He has a Bachelor's Degree in Civil Engineering and a Master's Degree in Public Administration major in Research and Development Planning.

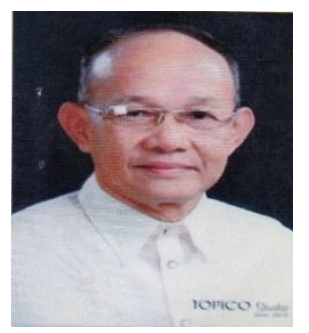

\section{Dr. Reynaldo C. Cruz}

He earned his Master of Arts Degree and Doctor of Education Degree from National Teachers College. He took special training in English Instruction in British Columbia, Canada, under the RPCanada World Youth Exchange Program. He served as Executive Vice President, Vice President for Academic Affairs, and Dean of the Graduate School of the La Consolacion University Philippines for many years. Dr. Cruz was a recipient of the Bulacan's2010 "DangalngLipi" award in education.

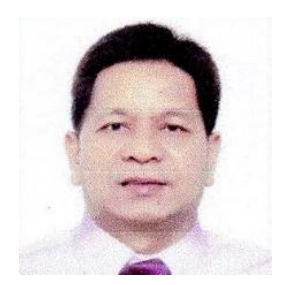

\section{Dr. Alberto J. Valenzuela}

He finished his Doctor of Education, Major in Educational Management at Bulacan State University, City of Malolos, Bulacan, Philippines. He is currently the Dean of BulSU-Bustos Campus. Prior to his assignment as Dean, he was a member of the BulSU's Board of Regents while serving his term as President of the Faculty Union. He is also the author of a research entitled; Recruitment and Selection Process of Faculty in the Higher Education Institutions in the Philippines which was published in the Int'l Conference Proceedings on Arts, Education and Interdisciplinary Studies (AEIS-16) at Dubai

UAE in 2016.

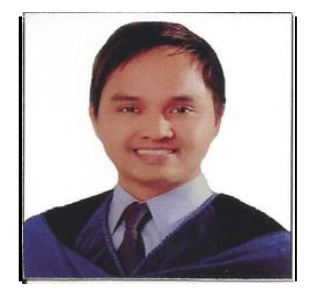

\section{Dr. Alvin V. Nuqui}

$\mathrm{He}$ is currently the Executive Vice President and Vice President for Academic Affairs of the La Consolacion University Philippines. He is also the Dean of the Graduate School of the LCUP. He is a graduate of Master of Arts in Behavioral Sciences and Doctor of Philosophy in Educational Management at LCUP. Dr. Nuqui is a lecturer at the Pamantasan ng Lungsod ng Maynila where he obtained hi Baccalaureate Degree in Physical Therapy and his "Gintong-Ani Award" for being an outstanding alumnus in March 2010. 